\title{
Determination of Antimicrobial and Antioxidant Activity of Some Spices Widely Consumed in Turkey
}

\section{Şenol KÖSE ${ }^{1^{*}}$}

\begin{abstract}
In the present study, antimicrobial and antioxidant properties of methanol extracts of some packaged and unpackaged spices including cinnamon (Cinnamomum zeylanicum), cumin (Cuminum cyminum L.), thyme (Thymus vulgaris L.) and mint (Mentha spicata L.) were determined. The antimicrobial effect of different concentrations of these spice extracts was examined by agar diffusion method against Escherichia coli, Enterococcus faecalis, Bacillus cereus, Pseudomonas aeruginosa and Salmonella typhimurium. While the antioxidant properties of spice extracts were examined using 2,2'-azino-bis-3ethylbenzthiazoline-6-sulphonic acid (ABTS) and 2,2-diphenyl-1-picryl-hydrazyl (DPPH) methods, the total phenolic components were examined using Folin-Ciocalteu method. Methanol extracts of spices showed antimicrobial activity at different rates against tested microorganisms. The methanol extract of unpackaged mint showed highest inhibiton zones $(22.50 \mathrm{~mm})$ against Salmonella typhimurium. When the total phenolic concentrations of spice extracts ranged from 6239.58 to $27197.92 \mathrm{mg} \mathrm{GAE} / \mathrm{kg}$, the ABTS values ranged from 40.75 to $667.57 \mathrm{mmol}$ Trolox/g dried spice and the percentage of DPPH inhibitions ranged from 88.98 to $96.26 \%$.
\end{abstract}

Keywords: Spices, antioxidant capacity, antibacterial effect, packaged, unpackaged

\section{Türkiye'de Yaygın Bir Şekilde Tüketilen Bazı Baharatların Antioksidan ve Antimikrobiyal Aktivitesinin Belirlenmesi}

ÖZET: Bu çalışmada ambalajlanmış ve ambalajlanmamış tarçın (Cinnamomum zeylanicum), kimyon (Cuminum cyminum L.), kekik (Thymus vulgaris L.) ve nanenin (Mentha spicata L.) metanol ektraktlarının antimikrobiyal ve antioksidan özellikleri belirlenmiştir. Bu baharat ekstrelerinin Escherichia coli, Enterococcus faecalis, Bacillus cereus, Pseudomonas aeruginosa ve Salmonella typhimurium'a karş1 antimikrobiyal etkisi agar difüzyon yöntemi ile belirlenmiştir. Baharat ekstrelerinin antioksidan özellikleri 2,2'-azino-bis-3-etilbenzotiazolin-6-sulfonik asit (ABTS) and 2,2-difenil-1-pikril-hidrazil (DPPH) yöntemleri kullanılarak incelenirken, toplam fenolik bileşikler Folin-Ciocalteu yöntemi kullanılarak incelenmiştir. Baharatların metanol ekstreleri test edilen mikroorganizmalara karşı farklı oranlarda antimikrobiyal aktivite göstermiştir. En yüksek inhibisyon aktiviteyi $(22.50 \mathrm{~mm})$ ambalajlanmamış nanenin metanol ekstresi Salmonella typhimurium'a karşı göstermiştir. Baharat özütlerinin toplam fenolik konsantrasyonları 6239.58 ile $27197.92 \mathrm{mg} \mathrm{GAE} \mathrm{/} \mathrm{kg} \mathrm{arasında} \mathrm{değiştiğinde,} \mathrm{ABTS} \mathrm{değerlerinin} 40.75$ ile 667.57 mmol Trolox / g kurutulmuş baharat ve DPPH inhibisyon yüzdesinin \% 88.98 ile \% 96.26 arasında değiştiği saptanmıştır.

Anahtar Kelimeler: Baharatlar, antioksidan kapasite, antibakteriyel etki, ambalajlanmış, ambalajlanmamış

Şenol KÖSE (Orcid ID: 0000-0003-0599-6030), Van Yüzüncü Y1l Üniversitesi, Mühendislik Fakültesi, G1da
Mühendisliği Bölümü, Van, Türkiye
*Sorumlu Yazar/Corresponding Author: Şenol KÖSE, e-mail: senolkose28@ gmail.com
Geliş tarihi / Received: 30-01-2020
Kabul tarihi / Accepted: 07-06-2020 


\section{INTRODUCTION}

Since antiquity times, herbs and spices have been used in human diet to improve the flavour, color and aroma of different types of food (Aliakbarlu et al., 2014). In addition to sensory effects, they have also been used for antioxidant (Embuscado, 2015) and antibacterial effects (Shan et al., 2007). Thus, they can be used as natural antioxidants and antimicrobials in food production processes (Kose and Ocak, 2018).

Many investigations have determined that phenolic compositions in spices considerably contributed to their antioxidant capacities (Cai et al., 2004; Wu et al., 2004; Shan et al., 2007). Some investigations indicate that the phenolic compositions present in spices and herbs may also play a important role in their antimicrobial effects (Hara-Kudo et al., 2004).

Antimicrobial and antioxidant abilities of some spices have been determined by many researchers (Kivanc and Akgul, 1986; Deans and Svoboda, 1989; Ozcan and Boyraz, 2000; Ozcan and Erkmen, 2001; Zheng and Wang, 2001; Shan et al., 2005; Hinneburg et al., 2006; Shan et al., 2007; Joe et al., 2009; Szabo et al., 2010; Aliakbarlu et al., 2014). However, there is no comparative study of unpackaged and packaged spices (thyme, cumin, mint and cinnamon) on antimicrobial and antioxidant characteristics. Therefore, the purpose of this investigation was to compare in terms of antimicrobial and antioxidant characteristics of packaged and unpackaged spices.

\section{MATERIALS AND METHODS}

\section{Spice Material and Preparation of Extracts}

The research material consist of four packaged and unpackaged spices such as thyme (Thymus vulgaris L.), cumin (Cuminum cyminum L.), mint (Mentha spicata L.) and cinnamon (Cinnamomum zeylanicum) which are sold in local markets in Van province of Turkey. Methanol was used as the solvent in the preparation of spice extracts which were analyzed for antimicrobial and antioxidant activity. Firstly, spices were dried at $40{ }^{\circ} \mathrm{C}$. A $1 \mathrm{~g}$ of powdered dried spices was put into a centrifuge tube, made up to $25 \mathrm{~mL}$ with methanol and shaking incubator (Heidolph Unimax 1010, Germany) were used in dark at room temparature for $2 \mathrm{~h}$. Following incubation, the homogenate was centrifuged at $4470 \mathrm{~g}$ (Hettich Zentrifugen Universal $32 \mathrm{R}$, Germany) for $20 \mathrm{~min}$ at $4{ }^{\circ} \mathrm{C}$ and then supernatant was taken and placed into sterile dark bottles. The above steps was performed twice using the pellet and then collected supernatants were combined and evaporated in rotary evaporator (IKA RV 10, Germany) at $40{ }^{\circ} \mathrm{C}$. For antimicrobial activity tests, the residue was dissolved with dimethyl sulfoxide (DMSO) and then completed to $25 \mathrm{~mL}$ with DMSO by filtration through filter paper (Whatman no: 1). However, for total phenolic substance and antioxidant capacity tests, the residue was dissolved in methanol and the total volume was brought to $25 \mathrm{ml}$ with methanol by filtration through filter paper (Whatman no:1). These stock extracts were stored at $-18{ }^{\circ} \mathrm{C}$ until used.

\section{Bacterial Cultures}

Three Gram negative bacteria (Salmonella typhimurium ATCC 13311, Pseudomonas aeruginosa ATCC 19429, Escherichia coli ATCC 11303) and two Gram positive bacteria (Enterococcus faecalis ATCC 33186, Bacillus cereus ATCC 11778) were used in this study. Fresh bacteria cultures (24-48 h) were kept in the refrigerator until use.

\section{Antibacterial Assay}

The antibacterial activities of packaged and unpackaged spices on Gram positive and negative bacteria was determined by agar well diffusion method (NCCLS, 1999). Methanol extracts of spices were sterilized by filtration through $0.45 \mu \mathrm{m}$ membrane filter. All of the microorganisms were incubated 
at $37 \pm 0.1{ }^{\circ} \mathrm{C}$ for $24 \mathrm{~h}$ by inoculation into Mueller Hinton Broth (Oxoid). After incubation, small amounts of bacterial colony was removed from fresh bacteria cultures and the density of bacterial suspensions was adjusted with sterile physiological solution against $0.5 \mathrm{Mc}$-Farland standard tubes. $100 \mu \mathrm{L}$ of prepared culture was spread on the Mueller-Hinton Agar and then $100 \mu \mathrm{L}$ of extract solution was impregnated into the wells of agar plates directly. The inoculated plates were incubated for $24 \mathrm{~h}$ at $37^{\circ} \mathrm{C}$. Following incubation, the diameter of inhibition zone was determined in $\mathrm{mm}$. As positive controls, Ampicillin $(10 \mu \mathrm{g})$ and Tetracycline $(30 \mu \mathrm{g})$ discs were used. DMSO and methanol solvents were also used as negative controls.

\section{Total Phenolics Content}

The total phenolic compounds of the extracts were determined using the Folin-Ciocalteu method (Yemis et al., 2008). A $150 \mu \mathrm{L}$ sample and $3 \mathrm{~mL} \mathrm{Na}_{2} \mathrm{CO}_{3}(2 \%)$ were added to the test tubes. Approximately 2 minutes later, $150 \mu \mathrm{L}$ of the Folin-Ciocalteu's reagent (1:1, v/v in water) was added, the mixture was mixed with vortex and kept $45 \mathrm{~min}$. in darkness at room temperature. The absorbance at $765 \mathrm{~nm}$ was read spectrophotometer (UV Mini-1240, Shimadzu, Japan). The total phenolic substance concentration was calculated from the calibration chart generated by the gallic acid and were recorded as gallic acid equivalents (GAE).

\section{Antioxidant Capacity DPPH assay}

The antioxidant capacity of the extracts of various spices were determined by DPPH·method (Brand- Williams et al., 1995). The DPPH solution (25 mg DPPH / L methanol) was dissolved daily in methanol and was diluted with methanol to an absorbance of $0.700 \pm 0.020$ at $520 \mathrm{~nm}$. A total of 100 $\mu \mathrm{L}$ sample was mixed with $2.4 \mathrm{ml}$ DPPH solution and the mixture was vortexed. After 30 min incubation in dark at room temperature, the absorbance at $520 \mathrm{~nm}$ was recorded. The antiradical activity of samples was calculated according to following equation;

$$
\% \text { inhibition of DPPH }=\frac{\text { Absorbance }(\text { Control })-\text { Absorbance }(\text { Sample })}{\text { Absorbance }(\text { Control })} * 100
$$

\section{ABTS assay}

ABTS radical cation was generated by mixing 7.0 mM ABTS stock solution with $2.45 \mathrm{mM}$ (final concentration) potassium persulfate (Re et al., 1999). After $12-16 \mathrm{~h}$, it was diluted with $80 \%$ ethanol to measure $0.700 \pm 0.2$ absorbance at $734 \mathrm{~nm} .2970 \mu \mathrm{L}$ of the diluted ABTS solution was taken in a test tube, $30 \mu \mathrm{L}$ of the spice extract was added and rapidly vortexed. After 6 minutes, the absorbance at 734 $\mathrm{nm}$ was measured in the spectrophotometer. The same procedure was performed for Trolox and the antioxidant activity value was recorded as Trolox equivalent (mmol Trolox eq/g dried weight).

\section{Statistical Analysis}

The collected data were expressed as means \pm standard deviation of triplicate measurements using the SPSS (V.20) package program. Duncan multiple comparison test was used to assigned to differences between the different group materials in the same package and t-test was used for comparison of different packaging materials within the same group.

\section{RESULTS AND DISCUSSIONS}

\section{Antimicrobial Activity}

The antibacterial effect of extracts against tested bacteria were shown in Table 1. The inhibition zones of extracts changed depending on the variety of spices, concentrations of spices, packaging and bacteria. 
The largest inhibition zone was found in the methanol extract of unpackaged mint spice against S.typhimurium $(22.50 \mathrm{~mm})$. Also, spices of unpackaged mint showed higher antibacterial effect than Tetracycline $(30 \mu \mathrm{g})$ against S.typhimurium. However, $40 \mathrm{mg} / \mathrm{ml}$ concentrations of extracts of all spices exhibited higher antibacterial effect than Ampicillin $(10 \mu \mathrm{g})$ antibiotic against $P$. aeruginosa.

In general, thyme has a higher antimicrobial efficacy than other spices used in different concentration and form of packages. This situation may be due to high content of phenolic components such as thymol and carvacrol. This is in accordance with, previous studies which showed that carvacrol and thymol had strong antibacterial activity (Cetin et al., 2011; Du et al., 2015). These components may inactivate the essential enzymes, disturb energy production and structural component synthesis and the genetic material functionally or react with the cell membrane activity (Celikel and Kavas, 2008).

Table 1. Antimicrobial activity of spice extracts

\begin{tabular}{|c|c|c|c|c|c|c|c|}
\hline \multirow[t]{2}{*}{ Spice } & \multirow[t]{2}{*}{ Concentration } & \multirow[t]{2}{*}{ Packaging type } & \multicolumn{4}{|c|}{ Inhibiton zone diameter $(\mathrm{mm})$} & \multirow[b]{2}{*}{ P.aeruginos: } \\
\hline & & & B.cereus & E.faecalis & E.coli & S.typhimurium & \\
\hline \multirow{4}{*}{ Thyme } & \multirow[t]{2}{*}{$40 \mathrm{mg} / \mathrm{ml}$} & \multirow{2}{*}{$\begin{array}{l}\text { Packaged } \\
\text { Unpackaged }\end{array}$} & 9 & - & 16.50 & 21 & 13.50 \\
\hline & & & 12 & 8.50 & 16 & 18 & 14.50 \\
\hline & \multirow[t]{2}{*}{$20 \mathrm{mg} / \mathrm{ml}$} & \multirow{2}{*}{$\begin{array}{l}\text { Packaged } \\
\text { Unpackaged }\end{array}$} & - & - & 10.50 & 16 & 9 \\
\hline & & & 9 & - & 9 & 13 & 9 \\
\hline \multirow{4}{*}{ Cumin } & \multirow[t]{2}{*}{$40 \mathrm{mg} / \mathrm{ml}$} & \multirow{2}{*}{$\begin{array}{l}\text { Packaged } \\
\text { Unpackaged }\end{array}$} & - & - & - & - & 9 \\
\hline & & & 13.50 & - & - & - & 18 \\
\hline & \multirow[t]{2}{*}{$20 \mathrm{mg} / \mathrm{ml}$} & \multirow{2}{*}{$\begin{array}{l}\text { Packaged } \\
\text { Unpackaged }\end{array}$} & - & - & - & - & - \\
\hline & & & - & - & - & - & - \\
\hline \multirow{4}{*}{ Mint } & \multirow[t]{2}{*}{$40 \mathrm{mg} / \mathrm{ml}$} & \multirow{2}{*}{$\begin{array}{l}\text { Packaged } \\
\text { Unpackaged }\end{array}$} & 9 & - & 17 & 19 & 12 \\
\hline & & & 10 & - & 14.50 & 22.50 & 16 \\
\hline & \multirow[t]{2}{*}{$20 \mathrm{mg} / \mathrm{ml}$} & \multirow{2}{*}{$\begin{array}{l}\text { Packaged } \\
\text { Unpackaged }\end{array}$} & - & - & - & 13 & 9 \\
\hline & & & 8 & - & - & 18 & 10.50 \\
\hline \multirow{4}{*}{ Cinnamon } & \multirow[t]{2}{*}{$40 \mathrm{mg} / \mathrm{ml}$} & \multirow{2}{*}{$\begin{array}{l}\text { Packaged } \\
\text { Unpackaged }\end{array}$} & - & - & - & 12.50 & 12 \\
\hline & & & - & 9 & - & 17.50 & 12 \\
\hline & \multirow[t]{2}{*}{$20 \mathrm{mg} / \mathrm{ml}$} & \multirow{2}{*}{$\begin{array}{l}\text { Packaged } \\
\text { Unpackaged }\end{array}$} & - & - & - & - & - \\
\hline & & & - & - & - & 14.50 & 8 \\
\hline \multicolumn{8}{|c|}{ Positive controls } \\
\hline \multicolumn{2}{|c|}{ Tetracycline $(30 \mu \mathrm{g})$} & & 26 & 18 & 21 & 22 & 12 \\
\hline \multicolumn{2}{|c|}{ Ampicillin $(10 \mu \mathrm{g})$} & & 20 & 25 & 24.50 & 33 & - \\
\hline \multicolumn{8}{|c|}{ Negative controls } \\
\hline \multicolumn{2}{|l|}{ Methanol } & & - & - & - & - & - \\
\hline \multicolumn{2}{|l|}{ DMSO } & & - & - & - & - & - \\
\hline
\end{tabular}

-: No inhibition zone.

The spice extracts had lower antibacterial effect against $E$. faecalis and also cumin extracts had lower antibacterial effect against tested bacteria. Positive controls Ampicillin (10 $\mu \mathrm{g})$ and Tetracycline $(30 \mu \mathrm{g})$ exhibited higher antibacterial activity than extracts against all of bacteria except for $P$. aeruginosa and negative controls (methanol and DMSO) didn't show any antibacterial activity.

It was examined that the methanol extracts of unpackaged spices showed higher antibacterial ability against tested bacteria in comparison to packaged spices. The Enterococcus faecalis ATCC 33186 was determined as the most resistant strain to packaged and unpackaged spices of methanol extracts.

As seen Table 1 Gram negative bacteria were more affected than Gram positive ones. Our results were similar with previous study of oregano and thyme spices for antimicrobial activity submitted by Cetin et al. (2011). The main differences between Gram positive and negative bacteria essentially are in the structure of their cell walls (Takahashi et al., 2004). 
It is known that the compositions of spices and their antibacterial effects based on variety of spices and conditions of region (Sagdic and Ozcan, 2003). Thus, further studies are needed for determination the compounds responsible for antibacterial activity of these extracts against tested bacteria.

\section{Total Phenolic Compounds and Radical Scavenging Activities}

The results of the total phenolics content and antioxidant capacities of packaged and unpackaged spices were shown in Table 2. According to the study we have done before (Kose and Ocak, 2018), methanol was better solvent than ethanol and aceton for extraction of phenolic compounds and antioxidants from plant materials due to polarity and good solubility. Phenolic substances generally have partial polar properties because they carry hydroxyl groups. In addition, phenolic substances are found in plant tissues, usually esterified with sugars, which increase the solubility of glycoside forms in relatively polar solvents such as water and methanol (Dagdelen, 2010). Similarly, in the study reported by Dagdelen et al. (2014), it was found that methanol was the best solvent to dissolve phenolic substances from plant spices. Therefore, in the current study methanol was used to extracting phenolic compounds and antioxidants from all spices.

Table 2. Total phenolic compounds and antioxidant capacities of spice extracts

\begin{tabular}{lllll}
\hline \multirow{2}{*}{ Samples } & TPC $(\mathbf{m g}$ GAE/kg) & $\begin{array}{l}\text { \% inhibition of } \\
\text { DPPH }\end{array}$ & $\begin{array}{l}\text { TEAC }(\mathbf{m m o l} \\
\text { Trolox/g) }\end{array}$ \\
\hline \multirow{3}{*}{ Packaged } & Thyme & $25046.88 \pm 994.37^{\mathrm{aC}}$ & $93.26 \pm 2.21^{\mathrm{aAB}}$ & $311.50 \pm 1.4^{\mathrm{aC}}$ \\
\cline { 2 - 5 } & Cumin & $6677.08 \pm 220.97^{\mathrm{aA}}$ & $94.43 \pm 1.73^{\mathrm{aB}}$ & $40.75 \pm 4.88^{\mathrm{aA}}$ \\
\cline { 2 - 5 } & Mint & $21942.71 \pm 125.21^{\mathrm{aB}}$ & $89.12 \pm 1.92^{\mathrm{aA}}$ & $192.65 \pm 20.23^{\mathrm{aB}}$ \\
\cline { 2 - 5 } & Cinnamon & $26296.88 \pm 169.42^{\mathrm{aC}}$ & $91.84 \pm 0.19^{\mathrm{aAB}}$ & $640.44 \pm 6.28^{\mathrm{aD}}$ \\
\hline \multirow{3}{*}{ Unpackaged } & Thyme & $22421.88 \pm 1377.38^{\mathrm{aC}}$ & $96.26 \pm 2.6^{\mathrm{aB}}$ & $308.54 \pm 1.4^{\mathrm{aC}}$ \\
\cline { 2 - 5 } & Cumin & $6239.58 \pm 176.78^{\mathrm{aA}}$ & $95.24 \pm 0.38^{\mathrm{aB}}$ & $55.06 \pm 1.39^{\mathrm{aA}}$ \\
\cline { 2 - 5 } & Mint & $17552.08 \pm 1414.21^{\mathrm{aB}}$ & $88.98 \pm 0.19^{\mathrm{aA}}$ & $176.87 \pm 42.55^{\mathrm{aB}}$ \\
\cline { 2 - 5 } & Cinnamon & $27197.92 \pm 397.75^{\mathrm{aD}}$ & $90.27 \pm 0.1^{\mathrm{bA}}$ & $667.57 \pm 1.39^{\mathrm{aD}}$ \\
\hline
\end{tabular}

Values were performed as means \pm standard deviation,

Mean values in the same column showed the different letters (a-b) between different packaging materials within the same group (P<0.05), Mean values in the same column showed the different letters (A-D) between different group materials in the same package $(\mathrm{P}<0.05)$.

Total phenolics of spices changed from 6239.58 to $27197.92 \mathrm{mg}$ GAE/kg dw. As seen table 2, the contents of total phenolics varied widely in the spice extracts determined. The average total phenolics of packaged spices were found to be higher than unpackaged spices except for cinnamon spices. On the other hand, cinnamon extracts had the highest phenolic contents among packaged and unpackaged spices. While the difference of total phenolic compounds between packaged and unpacked spices were non-significant, the difference between the packaged spice varieties and unpackaged spice varieties were found to be significant $(\mathrm{p}<0.05)$. The obtained data compared with the literature, thyme results were higher than the value determined by Roby et al. (2013) as $8.10 \mathrm{mg}$ GAE/g, cumin results were lower than the value determined by Thippeswamy and Naidu (2005) as $8.6 \mathrm{mg} \mathrm{GAE} / \mathrm{g}$, mint were lower than the value determined by Scherer et al. (2013) as $76.32 \mathrm{mg} \mathrm{GAE} / \mathrm{g}$, cinnamon results were higher than the value determined by Ereifej et al. (2016) as 121.6-187.1 mg GAE/100g. The concentration of total phenolic compounds varied significantly between the spices. These values has changed according to spice variety and experimental conditions such as, extraction solvent and method. 
Although there are many methods for determining the antioxidant activity of spice extracts, the DPPH is the most widely used method for the quantification of free radical scavenging activity. This method is depend on the spectrophotometric measurement of the reduction in the characteristic purple color of 2.2-diphenyl picrylhydrazyl (DPPH) as a stable free radical. The reason for this decrease in color is the sweeping of DPPH by these antioxidants in the presence of antioxidants that give electrons and hydrogen atoms (Brand-Williams et al. 1995). The percentage inhibitions for DPPH assay are ranged from 88.98 to 96.26 . The higher the number, the greater the hydrogen-donating ability and thus the higher the antioxidant activity of the spice extracts. Therefore, DPPH values have the highest antioxidant activities.

The DPPH inhibitions of unpackaged thyme and cumin were found to be higher than thyme and cumin in packaged. On the other hand, the mint and cinnamon in packaged had higher DPPH inhibitions than unpackaged mint and cinnamon. The difference of DPPH inhibitions among packaged and unpacked spices were non-significant except for cinnamon spice. The DPPH inhibition of cinnamon spice in packaged and in unpackaged was found to be significantly different $(p<0.05)$.

Unpackaged thyme extract had the highest DPPH inhibition and this situation could be due to high content of phenolic components such as carvacrol and thymol content, these phenolic components with known antioxidant activity (Tural and Turhan, 2017).

When the DPPH results of spice exctracts were compared with the literature, thyme, mint and cumin showed higher DPPH inhibition than the value determined by Embuscado (2015) as 52, 50.9, $32.7 \%$, respectively. Also, DPPH inhibition of cinnamon were higher than the value determined by Dalwadi et al. (2016) as 54.63\%. These values may have changed depending on the spice types, environmental conditions, solvent type and extraction methods.

In addition to DPPH assays, ABTS analyses are commonly used for measuring antioxidant capacities of herb and spice extracts (Dagdelen et al., 2014). The ABTS method is depend on the generation of a blue/green $\mathrm{ABTS}^{++}$that can be decreased by antioxidants (Floegel et al., 2011). ABTS values of spices changed from 40.75 to $667.57 \mathrm{mmol}$ Trolox $/ \mathrm{g} \mathrm{dw}$. The methanol extract of packaged and unpackaged cinnamon showed high both ABTS values and total phenolic compounds. Phenolic substances may be the main compounds responsible for antioxidant activities of spices. The strong positive correlation between antioxidant capacity and total phenolic component of herbs and spices has been previously reported (Aliakbarlu, 2014; Chan et al., 2016).

The ABTS values of thyme, cumin, mint and cinnamon have been determined (Shan et al., 2007; Wojdyło et al., 2007; Vallverdu-Queralt et al., 2014). However, the ABTS values of present study showed higher and lower levels when compared with the previous study (Scherer et al., 2013; VallverduQueralt et al., 2014; Dalwadi et al., 2016). Differences of these investigations could be due to different extraction procedure.

\section{CONCLUSIONS}

This is the first study to compare the antioxidant and antimicrobial abilities of packaged and unpackaged spices. The most used spices in Turkey were found to have high levels of total phenolic contents, antioxidant capacities and antimicrobial activity. Thus, these spices can be used as natural preservatives and antioxidants in food production systems, due to it's rich and pleasant aroma.

The total phenolic concentration, DPPH inhibition and antimicrobial activity of 4 packaged and 4 unpackaged spice extracts were different from eachother. The compositions responsible for total phenolics, antioxidant and antimicrobial activities of spices are still unclear. Thus, more studies are necessary to determine and characterize the bioactive compounds. 


\section{REFERENCES}

Aliakbarlu J, Mohammadi S, Khalili S, 2014. A Study on Antioxidant Potency and Antibacterial Activity of Water Extracts of Some Spices Widely Consumed in Iranian Diet. Journal of Food Biochemistry, 38: 159-166.

Brand-Williams W, Cuvelier ME, Berset C, 1995. Use of a Free Radical Method to Evaluate Antioxidant Activity. LWT-Food Science and Technology, 28 (1): 25-30.

Cai YZ, Luo Q, Sun M, Corke H. 2004. Antioxidant activity and phenolic compounds of 112 traditional Chinese medicinal plants associated with anticancer. Life Sciences, 74: 2157-2184.

Chan C-L, Gan R-Y, Corke H, 2016. The Phenolic Composition and Antioxidant Capacity of Soluble and Bound Extracts in Selected Dietary Spices and Medicinal Herbs. Journal of Food Science and Technology, 51:565-573.

Cetin B, Cakmakci S, Cakmakci R, 2011. The Investigation of Antimicrobial Activity of Thyme and Oregano Essential Oils. Turkish Journal of Agriculture and Forestry, 35:145-154.

Celikel N, Kavas G, 2008. Antimicrobial Properties of Some Essential Oils Against Some Pathogenic Microorganisms. Czech Journal of Food Sciences, 26: 174-181.

Dagdelen S, (2010). Determination of Antimicrobial and Antioxidant Effects, Aroma Profile and Some Chemical Properties of Important Herbs Species Added to Otlu Cheese., Inonu University Graduate School of Natural and Applied Sciences Department of Food Engineering, PhD Thesis (Printed).

Dagdelen S, Bilenler T, Durmaz G, Gokbulut I, Hayaloglu AA, Karabulut I, 2014. Volatile Composition, Antioxidant and Antimicrobial Activities of Herbal Plants Used In The Manufacture of Van Herby (Otlu) Cheese. Journal of Food Processing and Preservation, 38:1716-1725.

Dalwadi K, Elias J, Patel VH, Subhash R, 2016. Comparative Study of Antioxidant Properties of Cinnamon and Kokum In Aqueous and Methanolic Extracts. Department of Higher Education-Govarnment of Gujarat Journal of Science, August-September, 2016.

Deans SG, Svoboda KP, 1989. Antimicrobial Activity of Summer Savory (Satureja Hortensis L.) Essential Oil and Its Constituents. Journal of Horticultural Science and Biotechnology, 64: 205-210.

Du E, Gan L, Li Z, Wang W, Liu D, Guo Y, 2015. In Vitro Antibacterial Activity of Thymol and Carvacrol and Their Effects on Broiler Chickens Challenged with Clostridium Perfringes. Journal of Animal Science and Biotechnology, 6:58. doi: 10.1186/s40104-015-0055-7.

Embuscado ME, 2015. Spices and herbs: Natural sources of antioxidants- a mini review. Journal of Functional Foods, 18: 811-819.

Ereifej KI, Feng H, Rababah TM, Tashtoush SH, Al-U'datt, MH, Gammoh S, Al-Rabadi GJ, 2016. Effect of Extractant and Temperature on Phenolic Compounds and Antioxidant Activity of Selected Spices. Food and Nutrition Sciences, 7: (362-370).

Floegel A, Kim D-O, Chung S-J, Koo SI, Chun OK, 2011. Comparison of ABTS/DPPH Assays to Measure Antioxidant Capacity in Popular Antioxidant-Rich US Foods. Journal of Food Composition and Analysis, 24:1043-1048.

Hara-Kudo Y, Kobayashi A, Sugita-Konishi Y, Kondo K, 2004. Antibacterial Activity of Plants Used in Cooking for Aroma and Taste. Journal of Food Protection, 67:2820-2824.

Hinneburg I, Damien Dorman HJ, Hiltunen R. 2006. Antioxidant Activities of Extracts from Selected Culinary Herbs and Spices. Food Chemistry, 97:122-129.

Joe MM, Jayachitra J, Vijayapriya M, 2009. Antimicrobial Activity of Some Common Spices Against Certain Human Pathogens. Journal of Medicinal Plants Research, 3(11):1134-1136.

Kıvanc M, Akgul A. 1986. Antibacterial Activities of Essential Oils from Turkish Spices and Citrus. Flavour and Fragrance Journal, 1:175-179.

Kose S, Ocak E, 2018. Antimicrobial and Antioxidant Properties of Sirmo (Allium vineale L.), mendi (Chaerophyllum macropodum Boiss.) and Siyabo (Ferula rigidula DC.). Gida 43(2): 294-302, doi: 10.15237/gida.GD17099.

NCCLS (National Committee for Clinical Laboratory Standard), 1999. Performance Standards for Antimicrobial Susceptibility Testing. 9th International Supplement. M100-S9. Wayne Pa. 
Ozcan M, Boyraz N, (2000). Antifungal Properties of Some Herb Decoctions. European Food Research and Technology, 212: 86-88.

Ozcan M, Erkmen O, 2001. Antimicrobial Activity of The Essential Oils of Turkish Plant Spices. European Food Research and Technology, 212: 658-660.

Re R, Pellegrini N, Proteggente A, Pannala A, Yang M, Rice-Evans C, 1999. Antioxidant Activity Applying an Improved ABTS Radical Cation Decolorization Assay. Free Radical Biology and Medicine, 26:12311237.

Roby MHH, Sarhan MA., Selim KAH, Khalel KI, 2013. Evaluation of Antioxidant Activity, Total Phenols and Phenolic Compounds in Thyme (Thymus vulgaris L.), Sage (Salvia officinalis L.), and Marjoram (Origanum majorana L.) Extracts. Industrial Crops and Products, 43:827-831.

Sagdic O, Ozcan M, 2003. Antibacterial Activity of Turkish Spice Hydrosols. Food Control. 14:141-143.

Scherer R, Lemos MF, Lemos MF, Martinelli GC, Martins JDL, Da Silva AG, 2013. Antioxidant and Antibacterial Activities and Composition of Brazilian Spearmint (Mentha spicata L.). Industrial Crops and Products, 50:408-413.

Shan B, Cai YZ, Sun M, Corke H. 2005. Antioxidant Capacity of 26 Spice Extracts and Characterization of Their Phenolic Constituents. Journal of Agricultural and Food Chemistry, 53:7749-7759.

Shan B, Cai YZ, Brooks JD, Corke H, (2007). The in Vitro Antibacterial Activity of Dietary Spice and Medicinal Herb Extracts. International Journal of Food Microbiology, 117:112-119.

Szabo MR, Radu D, Gavrilas S, Chambre D, Iditoiu C, 2010. Antioxidant and Antimicrobial Properties of Selected Spice Extracts. International Journal of Food Properties, 13(3):535545, DOI: $10.1080 / 10942910802713149$.

Takahashi T, Kokubo R, Sakaino M, 2004. Antimicrobial Activities of Eucalyptus Leaf Extracts and Flavonoids from Eucalyptus Maculata. Letters in Applied Microbiology, 39:60-64.

Thippeswamy NB, Akhilender Naidu K, 2005. Antioxidant Potency of Cumin Varieties-Cumin, Black Cumin and Bitter Cumin- on Antioxidant Systems. European Food Research and Technology, 220:472-476.

Tural S, Turhan S, 2017. Antimicrobial and Antioxidant Properties of Thyme (Thymus vulgaris L.), Rosemary (Rosmarinus officinalis L.) and Laurel (Lauris nobilis L.) Essential Oils and Their Mixtures. GIDA 42(5):588-596 doi: 10.15237/gida.GD17030.

Vallverdu-Queralt A, Regueiro J, Martinez-Huelamo M, Alvarenga JFR, Leal LN, Lamuela-Raventos RM, 2014. A Comprehensive Study on The Phenolic Profile of Widely Used Culinary Herbs and Spices: Rosemary, Thyme, Oregano, Cinnamon, Cumin and Bay. Food Chemistry, 154:299-307.

Yemis O, Bakkalbasi E, Artık N, 2008. Antioxidant Activities of Grape (Vitis Vinifera) Seed Extracts Obtained from Different Varieties Grown in Turkey. Journal of Food Science and Technology, 43:154-159.

Wu X, Beecher GR, Holden JM, Haytowitz DB, Gebhardt SE, Prior RL, 2004. Lipophilic and Hydrophilic Antioxidant Capacities of Common Foods in the United States. Journal of Agricultural and Food Chemistry, 52:4026-4037.

Wojdylo A, Oszmianski J, Czemerys R, 2007. Antioxidant Activity and Phenolic Compounds in 32 Selected Herbs. Food Chemistry, 105: 940-949.

Zheng W, Wang SY, 2001. Antioxidant Activity and Phenolic Compounds in Selected Herbs. Journal of Agricultural and Food Chemistry, 49: 5165-5170. 